\title{
Research on the Influence Depth of Soil with Different Burn Severity in the Burned Areas of E'gu Village in Yajiang County
}

\author{
Wang Yan ${ }^{1}$, Hu Xiewen ${ }^{1,2, *}$, Jin Tao ${ }^{1}$, Yang Ying ${ }^{1}$, Chao Xichao ${ }^{1}$ \\ ${ }^{1}$ Faculty of Geosciences and Environment Engineering, Southwest Jiaotong University, Chengdu, China \\ ${ }^{2}$ State-province Joint Engineering Laboratory of Spatial Information Technology for High-Speed Railway Safety, Chengdu, China
}

Email address:

yanwang $@$ my.swjtu.edu.cn (Wang Yan), huxiewen $a$ 163.com (Hu Xiewen)

${ }^{*}$ Corresponding author

\section{To cite this article:}

Wang Yan, Hu Xiewen, Jin Tao, Yang Ying, Chao Xichao. Research on the Influence Depth of Soil with Different Fire Severity in the Burn Areas of E'gu Village in Yajiang County. Earth Sciences. Vol. 8, No. 6, 2019, pp. 317-322. doi: 10.11648/j.earth.20190806.12

Received: August 21, 2019; Accepted: November 14, 2019; Published: November 18, 2019

\begin{abstract}
The high temperature caused by forest fires often leads to changes of soil properties, however, there is few detailed studies on the influence depth of soil properties caused by different fire severities. Taking the burned areas of E'Gu Village in Yajiang County as the research object, the influence depth of soil with different fire severity was revealed with the help of field and laboratory experiments in this paper. According to the research results, the influence depth of forest fire on soil natural density, bulk density and porosity is less than $2 \mathrm{~cm}$, and the influence depth on moisture content is more than $2 \mathrm{~cm}$. But only in the severely burned soil, the bulk density and porosity behaved significant differences when contrast to unburnt soil. The influence depth of lightly burn on soil water repellency was $1 \mathrm{~cm}$, and the influence depth of moderately and severely burn on soil water repellency is $3 \mathrm{~cm}$. In addition, the variation of soil repellency in burned area was in direct proportion to burn severity. The influence depth of forest fire on soil permeability is not more than $4 \mathrm{~cm}$, and the influence of lightly burn on soil permeability is not significant, while in moderately and severely burned areas, the soil permeability changes significantly.
\end{abstract}

Keywords: Burn Severity, Soil Physical Properties, Water Repellency, Permeability, Influence Depth

\section{Introduction}

Forest fires often lead to the change of soil properties, furtherly damage the forest ecosystem and soil anti-erosion ability [1,2], which is often a significant cause of the frequent occurrence of secondary disasters such as torrential floods and debris flows after burning. According to the research conducted by Hubbert et al [3], forest fire will cause the soil bulk density to increase, and moisture content and porosity to decrease. Wang Weixia et al [1] pointed out that the soil pore space will be filled with fine particles after burn, which could account for the decrease of porosity. According to the research on the moderate burned areas in Greater Khingan Range conducted by Sun Long et al [4], the decrease of soil moisture content caused by forest fires could sustain 12 years after fire, while the soil porosity will continue 20 years. Meanwhile, organic content of soil will decrease after burning [5]. It was pointed out by Jiménez-Pinilla et al [6] that the soil repellency increased sharply after burn, but gradually disappeared as time goes by. Research conducted by Pereira et. all [7] indicate the recovery of water repellency after 9 months from fire. The change of soil repellency after burn is related to the consumption of soil organic matter by forest fire [8], as well as fire severity [9]. Through laboratory experiments, Wieting et al. [10] proved that soil permeability decreased significantly after fire. Alcaiz et al. [11] indicated that the influence of forest fire on soil was related to the soil properties and vegetation types before burn.

The change of soil properties after burn is mainly caused by the high-temperature baking effect in burning. In the in-situ burning experiments conducted by Gimeno-García et al [12] shown a mean temperature of $200 \sim 400^{\circ} \mathrm{C}$ on soil surface, with a highest temperature of $600^{\circ} \mathrm{C}$. And the fuel reserve on soil surface also controls the burning 
temperature [13]. According to Du Qiu et al [14], the increase of soil temperature caused by burn decreases as the depth increases in the burning experiment of mixed broadleaf-conifer forest. Similarly, the changes of soil properties caused by forest fires will also vary with the change of depth. However, few researches are related to the influence depth of forest fires on soil, especially the detailed research on influence depth of different fire intensity on soil properties in high altitude mountainous areas where there is a large amount of fuel reserve such as litter layers.

Taking the burned areas on the left of E'gu River basin in E'gu Town, Yajiang County, Sichuan Province, in-situ tests and indoor supplementary test are conducted aiming to reveal the influence depth in different burn severity.

\section{Study Area}

The stratum lithology of the burned areas on the left of E'gu River basin in E'gu Town, Yajiang County, Sichuan Province is mainly Triassic with metamorphous slate. The soil type of the surface slope is gravel loam, and in terms of geomorphology, it is alpine and gorge region. The climate in the research area has distinct dry and wet seasons, with total precipitation from May to October accounting for $94.19 \%$ of the year. The altitude is $3029 \sim 4474 \mathrm{~m}$, mainly with the masson pine coniferous forest and green ridge broad-leaved forest, and the research object in this paper is the soil of coniferous forest. On February 16th, 2018 (lunar New Year's Day), a severe forest fire caused by improper processing of local ritual fire lead to a burned area reaching $20.59 \mathrm{~km}^{2}$. The vegetation coverage of the E'gu River basin before the fire was about $98 \%$. The high temperature generated by the fire burning the soil under the forest, resulting in the obvious change of the soil physical and hydrological characteristics, which seriously impacted the hydrological response characteristics and erosion resistance of the soil. The in-situ sampling and test were carried out in the third week after the fire. During this period, there was no rainfall in the burned area, and there was only a small amount of snowfall for 2 or 3 times. The soil dry and wet circulation caused by melted snow has no significant effect on the soil properties.

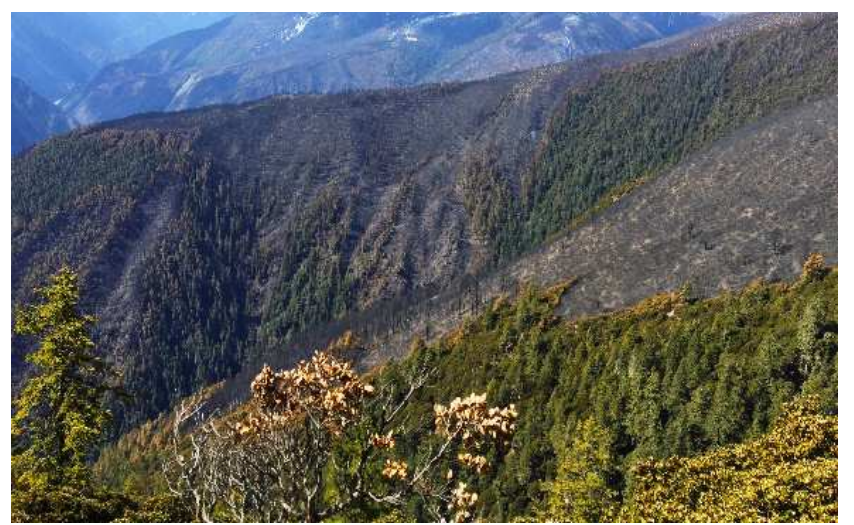

Figure 1. A view of the burned area in E'gu.

\section{Research Methods}

\subsection{Burn Severity}

Considering the fact that the change of soil properties is mainly caused by the burning of surface fuel, the burning severity was classified in this paper according to the burning degree of litter layer on the burned surface (As shown in Table 1). In order to study the influence depth of forest fire on soil, the physical properties and hydrological characteristics of soil under different burning degrees were measured

Table 1. Distinguishing Features of Different Burning Intensity [15].

\begin{tabular}{ll}
\hline Burning intensity & Features \\
\hline Unburnt & No change in surface covering before and after fire \\
Lightly burn & More than $50 \%$ of litter is not completely burned \\
Moderately burn & $\begin{array}{l}\text { Most of the litter is burned, but most of the crude } \\
\text { combustibles are not completely burned. }\end{array}$ \\
Severely burn & $\begin{array}{l}\text { Litter as well as crude combustibles is completely } \\
\text { burnt and the surface was covered with ash }\end{array}$ \\
\hline
\end{tabular}

\subsection{Determination of Soil Physical Properties}

The cutting-ring method was used to determine the soil physical properties. 12 sampling points were randomly selected from the soil in the area with different burning severities. One set of cutting-ring sample was taken at $0 \sim 2 \mathrm{~cm}$ and $2 \sim 4 \mathrm{~cm}$ respectively used to determine the soil property through laboratory test. Soil moisture content was determined by oven drying method, soil dry density was calculated by soil natural density and moisture content, and total soil porosity was calculated by soil density and soil particle density.

\subsection{Determination of Soil Hydrological Characteristics}

The changes in soil hydrological characteristics caused by forest fires are mainly reflected in soil water repellency and permeability. Water Drop method was used to test the water repellency on soil surface, with the repellency grade referring to Water Drop Penetration Time (WDPT). Values of WDPT represent the dynamic variation of contact angle on the surface between water drop and soil surface. During the tests, sampling points are randomly selected in different fire intensity areas to carry out water repellency, the residual ash and chars were swept, and chose the spare soil for tests. In order to reveal the distribution of water repellency along soil depth, four depths were chosen for water drop tests, including $0 \mathrm{~cm}, 1 \mathrm{~cm}, 2 \mathrm{~cm}$ and $3 \mathrm{~cm}$. The repellency was classified into 7 grades for statistical analysis based on the WDPT (As shown in Table 2).

Table 2. WDPT classification criterial [16].

\begin{tabular}{ll}
\hline Class & Time interval(s) \\
\hline$<5^{*}$ & $<5^{*}$ \\
10 & $6 \sim 10$ \\
30 & $11 \sim 30$ \\
60 & $31 \sim 60$ \\
180 & $61 \sim 180$ \\
300 & $181 \sim 300$ \\
$>300$ & $>300$ \\
\hline
\end{tabular}

$*$ WDPT $<5$ s represent water hydrophilic 


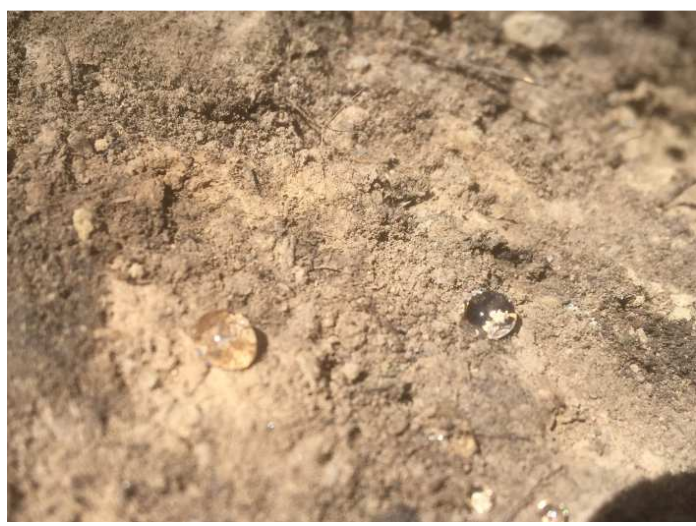

Figure 2. WDPT test on burned soil.

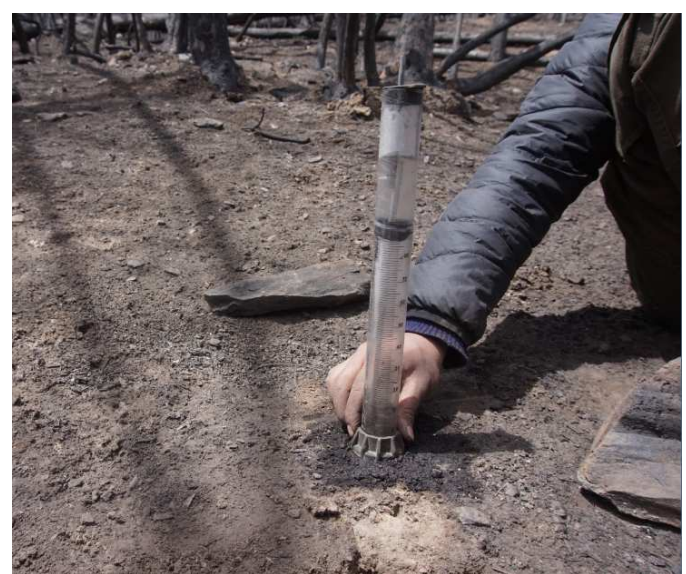

Figure 3. Permeability tests using mini-disk infitrometer.
With the help of Decagon's Mini disk infiltrometer, the soil permeability was measured by disc infiltration test at $2 \mathrm{~cm}$ intervals in burned areas with different fire intensity. This is a type of tension infiltration meter to test the permeability of soil matrix, ignoring the crack and large pore in soil. Tension infiltration meter could void the influence of randomly distributed cracks and large pore to soil infiltration rate. Soil infiltration parameters can be calculated by Philip infiltration formula.

$$
I=C_{1} \sqrt{t}+C_{2} \mathrm{t}
$$

Where: I - Cumulative infiltration amount $/ \mathrm{cm}$; $\mathrm{T}$ - Infiltration duration/s;

$C_{1}-\left(\mathrm{m} / \mathrm{s}^{1 / 2}\right), C_{2}(\mathrm{~m} / \mathrm{s})$ the coefficient related to soil infiltration. Where, $C_{1}$ refers to the soil sorptivity $S$, and soil sorptivity was calculated by intercepting data of the first 300 seconds in water infiltration[10], and the saturated hydraulic conductivity $\left(\mathrm{k}_{f s}\right)$ can be calculated by $C_{2}$ in steady infiltration [17]:

$$
\begin{gathered}
S=C_{1} \\
k=\frac{C_{2}}{A}
\end{gathered}
$$

Where: $\mathrm{k}$ represent the soil saturate hydraulic conductivity; $A$ is the parameter of van Genuchten model in the condition of giving soil type, negative osmotic pressure and disk radius. The value was taken as 3.89 in this research.
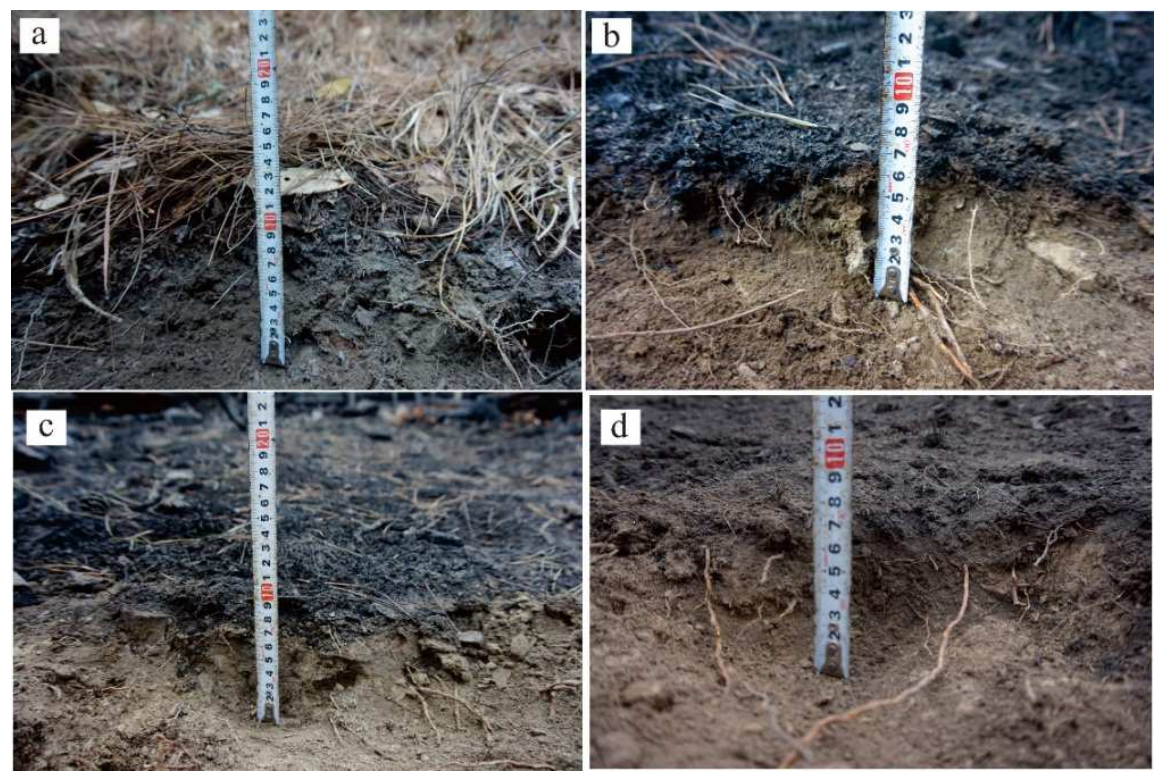

Figure 4. Soil profile with different burn severity: a represents unburnt; b represents slightly burn; c represents moderately burn; $d$ represents severely burn.

\section{Results}

\subsection{Changes in Soil Physical Properties}

Significance testing was used to analyze the mean value of soil physic parameters. As shown in Table 3, taking the samples in the unburnt area as the control group, the natural density of soils at the depth of $0-2 \mathrm{~cm}$ decreased slightly in the lightly burned area, without significant difference. But in the moderately and severely burned area, the natural soil density shown significant difference. The moisture contents in the burned area were significantly lower than that in the unburned area, and decreased 
progressively with the severity of the burning. It is shown in the data that only the bulk density and porosity in the severely burned area showed significant differences. However, for the soil in the burned area at a depth of $2 \sim 4 \mathrm{~cm}$, only the moisture content of the soil in the burned area showed significant difference compared with that in the unburned area, but there was no significant difference in different burn severity. It can be seen that the influence depth of forest fire on soil porosity and dry density is $2 \mathrm{~cm}$, while the influence depth of forest fire on moisture content is more than $2 \mathrm{~cm}$.

\subsection{Changes in Soil Hydrological Characteristics}

As shown in Figure 5, according to the Water Drop Penetration Test, the soil water repellency decreases with increasing soil depth in both burned and unburned areas. The percent of water repellent soil (WRS) at surface range from $43 \%$ to $86 \%$, but at the depth of $1 \mathrm{~cm}, 2 \mathrm{~cm}, 3 \mathrm{~cm}$, the percent of WRS were $7 \% \sim 48 \%, 3 \% \sim 12 \%$ and $3 \% \sim 6 \%$ separately. In addition, the repellency in burned areas increase significantly and gradually along with the increase of burn severity. When it comes to surface soil, the content of WRS was $43 \%$, but increased to $60 \%, 84 \%$ and $86 \%$ separately in lightly burnt, moderately burnt and severely burnt areas, which indicated that most of the soil in moderately and severely burned areas were hydrophobic.

Along with the increasing depth of soil, the effect of fire on soil decreased gradually. At the depth of $1 \mathrm{~cm}$, percent of WRS was $7 \%$ in unburnt area and $6 \%$ in slightly burnt area, showing no significant difference and a maximum influence depth of $1 \mathrm{~cm}$ in slightly burned area. But the WRS in moderately and severely burned area were still different at the depth of $1 \mathrm{~cm}$. Until the soil depth of $3 \mathrm{~cm}$, the WRS in unburned, slightly burned, moderately burned and severely burned areas were $3 \%, 4 \%, 4 \%$ and $6 \%$ in separate, indicating an influence depth of $3 \mathrm{~cm}$ in moderately and severely burned areas.

Table 3. The soil physical characteristics with different burn severity.

\begin{tabular}{|c|c|c|c|c|c|}
\hline Depth & Burn severity & Natural density $\left(\mathrm{g} / \mathrm{cm}^{3}\right)$ & Water content $(\%)$ & Bulk density $\left(\mathrm{g} / \mathrm{cm}^{3}\right)$ & Porosity (\%) \\
\hline \multirow{3}{*}{$0-2 \mathrm{~cm}$} & Unburnt & $1.23 \mathrm{a}(0.08)$ & 15.72 a $(0.69)$ & $1.06 \mathrm{a}(0.08)$ & $59.64 \mathrm{a}(3.06)$ \\
\hline & Lightly burn & $1.20 \mathrm{a}(0.05)$ & $9.73 \mathrm{~b}(1.27)$ & $1.09 \mathrm{a}(0.05)$ & 58.55 a (1.97) \\
\hline & Moderately burn & $1.16 \mathrm{~b}(0.12)$ & $6.54 \mathrm{c}(2.87)$ & $1.09 \mathrm{a}(0.09)$ & $58.47 \mathrm{a}(3.58)$ \\
\hline \multirow{3}{*}{$2-4 \mathrm{~cm}$} & Unburnt & $1.41 \mathrm{a}(0.11)$ & $6.65 \mathrm{a}(2.37)$ & $1.32 \mathrm{a}(0.10)$ & $49.70 \mathrm{a}(3.89)$ \\
\hline & Lightly burn & $1.36 \mathrm{a}(0.09)$ & $4.42 \mathrm{~b}(0.25)$ & $1.30 \mathrm{a}(0.09)$ & $50.50 \mathrm{a}(3.23)$ \\
\hline & Moderately burn & $1.39 \mathrm{a}(0.04)$ & $4.26 \mathrm{~b}(0.60)$ & $1.33 \mathrm{a}(0.04)$ & $49.49 \mathrm{a}(1.67)$ \\
\hline
\end{tabular}

Mean values followed by the same letter in the same row were not significantly different $(\mathrm{p}<0.05)$.
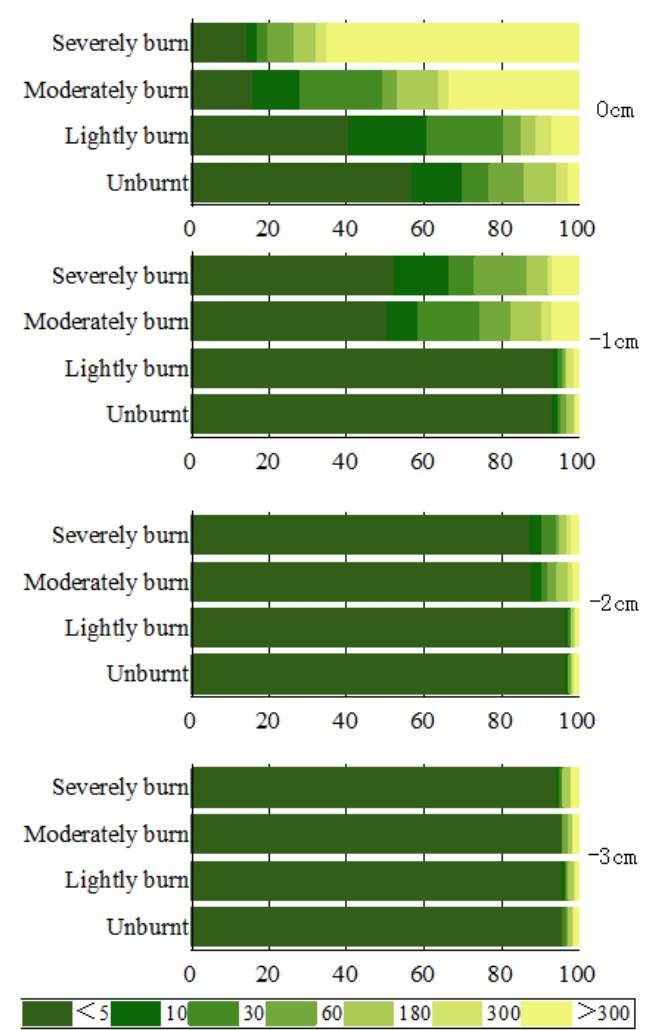

Figure 5. Change of soil water repellency.
Figure 6 and Figure 7 analyze the relationship between soil permeability and WDPT, in which the distance from the WDPT test site to mini-disk test sites less than $10 \mathrm{~cm}$ so as to ensure the little difference between these two sites. The saturated hydraulic conductivity was inversely linked to WDPT values, their relationship follows the law of power function: $\mathrm{K}=0.00034 W D P T^{-0.29}\left(R^{2}=0.85\right)$. The soil sorptivity was also inversely linked to WDPT values, their relationship follows the law of power function: $S=0.012 W D P T^{-0.26}$ $\left(R^{2}=0.89\right)$. This phenomenon illustrates that when the soil water repellency was more severe, the water was less easily to penetrate soil surface, resulting the decrease of soil saturated hydraulic conductivity and sorptivity.

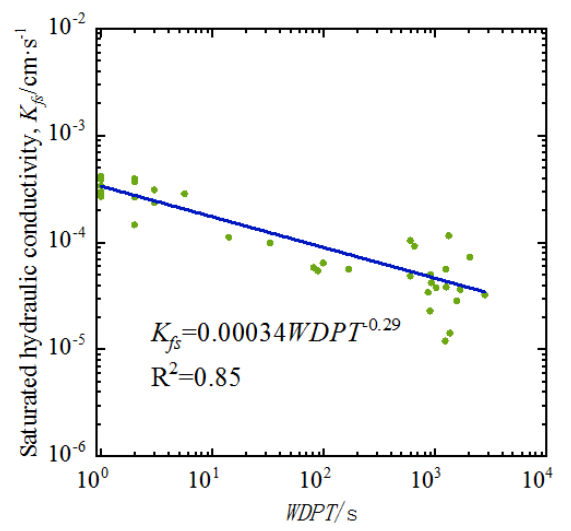

Figure 6. Relationship between saturated hydraulic conductivity and WDPT. 


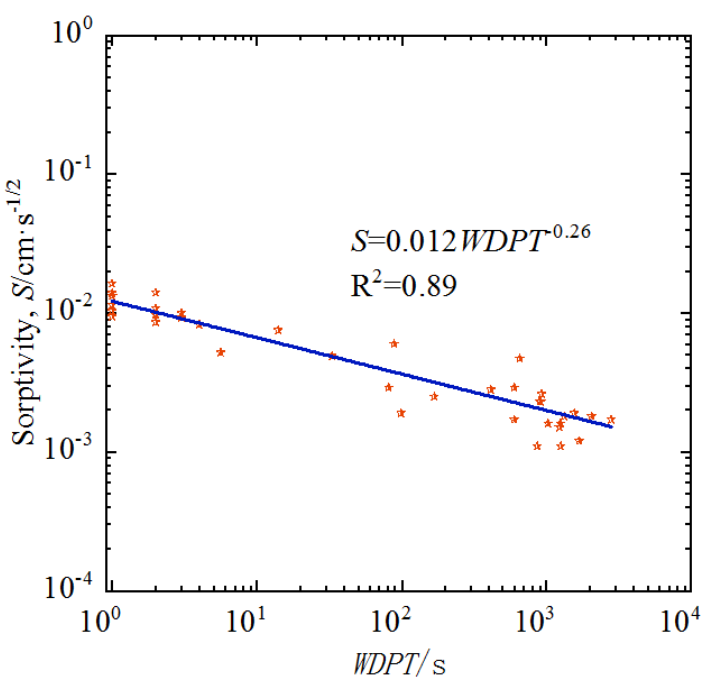

Figure 7. Relationship between sorptivity and WDPT.

Figure 8 and Figure 9 indicate the change of soil saturated hydraulic conductivity and sorptivity with different depth and different burn severity. Because the surface cover in unburnt and slightly burnt area were unfired or charred litter layer, the infiltration parameters of surface cover were replaced by that of ash layer. According to the data, the burning has the greatest impact on the permeability of the topsoil. Compared with the unburned area, the changes in soil saturated water conductivity and sorptivity in burned area gradually decreases with the increase of depth until the soil depth is $4 \mathrm{~cm}$. When compared with unburned area, the soil saturated hydraulic conductivity $(K)$ in slightly, moderately, and severely burned areas decreased $10 \%, 62 \%$ and $72 \%$ separately at soil surface, $11 \%, 40 \%$ and $29 \%$ in depth of $2 \mathrm{~cm}$. There was no significant variation of $K$ value among different burn severities in soil depth of $4 \mathrm{~cm}$. In contrast to unburned area, the sorptivity of surface soil in slightly, moderately and severely burned areas decreased $12 \%, 65 \%$ and $73 \%$ respectively. The variation of soil sorptivity in different burn severity decreased with increasing depth too. Until $4 \mathrm{~cm}$ in soil depth, the differences became little. In addition, the comparison of soil permeability in different burn severity shown the little changes in lightly burned area, but obvious changes in moderately and severely burned areas.

\section{Discussion}

Restricted by the experimental methods (the interval depth of soil cutting-ring sampling and disc infiltration are $2 \mathrm{~cm}$, and the interval depth of water drop infiltration is $1 \mathrm{~cm}$ ), forest fire has different impacts on soil physical and hydrological properties according to the final data. However, it also indicated that the impacts of forest fire on soil physical and hydrological properties began to reduce to zero at $2 \sim 4 \mathrm{~cm}$ depth. Badía et al [18] documented an influence depth of $4 \mathrm{~cm}$ in soil moisture and $3 \mathrm{~cm}$ in soil water repellency, which agree with the results in this study. Indicated by Bradstock et al [19] and Beyers[20], more than half of the temperature decreased in the soil depth of $2 \sim 5 \mathrm{~cm}$ in contrast to soil surface. This may express why the there is little change of soil characteristics over the depth of $2 \sim 4 \mathrm{~cm}$.

Saturated hydraulic conductivity, K $\left(10^{-4} \mathrm{~cm} / \mathrm{s}\right)$

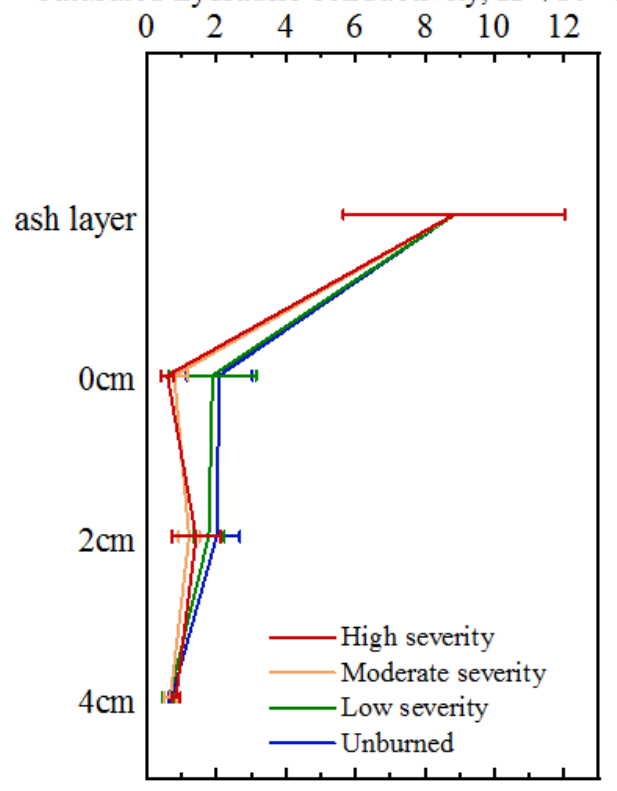

Figure 8. Change of saturated hydraulic conductivity in different soil depth.

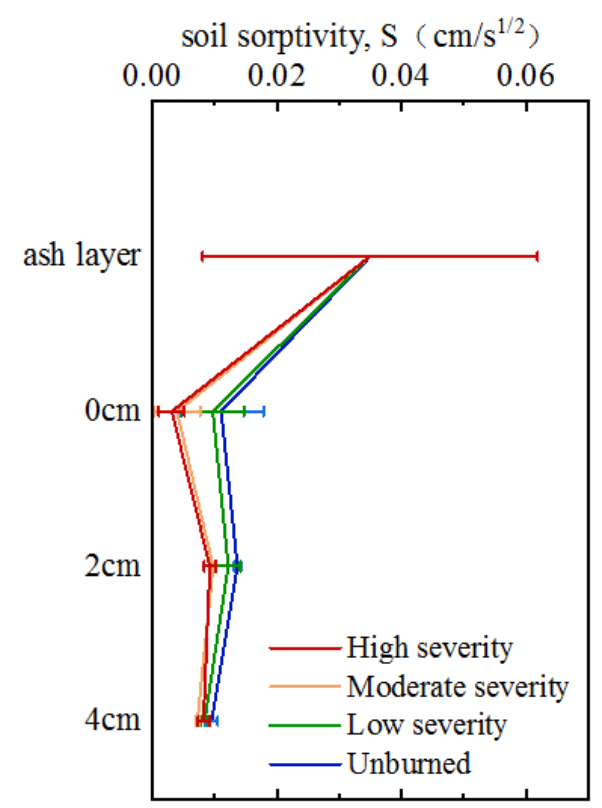

Figure 9. Change of sorptivity in different soil depth.

In different areas with different burn severity, the influence degree and depth of forest fire on soil shown significant differences. The light burn has slight effect on soil, but the soil properties significantly changed in moderately and severely burned areas. Loudermilk et al [21] documented the variation and distribution of surface fuel will control the fire severity. Different burn severities always accompany with different burning degree of litter layer [22], resulting of variation of fire-influence depth in soil, because the burning degree of litter layer determine the baking degree of sub-soil. 


\section{Conclusion}

According to the research on the influence of different burn severty on the soil in the burned areas of E'gu Village in Yajiang County, the influence depth of forest fire on soil properties is greatly affected by burn severity.

1) The influence depth of forest fire on soil natural density, bulk density and porosity were less than $2 \mathrm{~cm}$, and that on moisture content was more than $2 \mathrm{~cm}$. The influence degree of forest fire on soil physical properties increases with the increase of fire intensity.

2) The influence depth of light burn on soil water repellency was $1 \mathrm{~cm}$, and the influence depth of moderate and severe burn on soil repellent was $3 \mathrm{~cm}$. The changing degree of soil repellency was in direct proportion to the fire intensity.

3) The influence depth of forest fire on soil permeability is not more than $4 \mathrm{~cm}$. The lightly burn has no significant effect on soil permeability, however, in in moderately and severely burned areas, the soil permeability changes significantly.

\section{Acknowledgements}

This paper was found by National Natural Science Foundation of China (Grant No.41672283 and No. 41731285) Thanks the Township government for giving us help in the in-situ experiments.

\section{References}

[1] W. Weixia, L. Xiaoju, L. Jing et. all. Effects of Moderate Fire Disturbance on Soil Physical and Chemical Properties in Kanas Taiga Forests. Southwest China Journal of Agricultural Sciences. 2018, 31 (06): 1216-1220.

[2] Benavides-Solorio J, Macdonald L H. Post-fire runoff and erosion from simulated rainfall on small plots, Colorado Front Range. Hydrological Processes. 2001, 15 (15): 2931-2952.

[3] Hubbert K R, Preisler H K, Wohlgemuth P M, et al. Prescribed burning effects on soil physical properties and soil water repellency in a steep chaparral watershed, southern California, USA. Geoderma. 2006, 130 (3-4): 284-298.

[4] S. Long, Z. Jun, H. Haiqing. Effect of Moderate Fire Disturbance on Soil Physical and Chemical Properties of Betula platyphylla-Larix gmelinii Mixed Forest. SCIENTIA SILVAE SINICAE. 2011, 47 (02): 103-110.

[5] Fox D M, Darboux F, Carrega P. Effects of fire-induced water repellency on soil aggregate stability, splash erosion, and saturated hydraulic conductivity for different size fractions. Hydrological Processes. 2010, 21 (17): 2377-2384.

[6] Jiménez-Pinilla P, Lozano E, Mataix-Solera J, et al. Temporal changes in soil water repellency after a forest fire in a Mediterranean calcareous soil: Influence of ash and different vegetation type. Science of The Total Environment. 2016, 572 : 1252-1260.

[7] Pereira P, úbeda X, Mataix-Solera J, et al. Short-term changes in soil Munsell colour value, organic matter content and soil water repellency after a spring grassland fire in Lithuania. Solid Earth. 2014, 5 (1): 209-225.

[8] Jordán A, Zavala L M, Mataix-Solera J, et al. Effect of fire severity on water repellency and aggregate stability on Mexican volcanic soils. CATENA. 2011, 84 (3): 136-147.

[9] Lewis S A, Wu J Q, Robichaud P R. Assessing burn severity and comparing soil water repellency, Hayman Fire, Colorado. Hydrological Processes. 2006, 20 (1): 1-16.

[10] Wieting C, Ebel B A, Singha K. Quantifying the effects of wildfire on changes in soil properties by surface burning of soils from the Boulder Creek Critical Zone Observatory. Journal of Hydrology: Regional Studies. 2017, 13: 43-57.

[11] Alcañiz M, Outeiro L, Francos M, et al. Effects of prescribed fires on soil properties: A review. Science of The Total Environment. 2018, 613-614: 944-957.

[12] Gimeno-García E, Andreu V, Rubio J L. Spatial patterns of soil temperatures during experimental fires. Geoderma. 2004, 118 (1): 17-38.

[13] Bradstock R A, Auld T D. Soil Temperatures During Experimental Bushfires in Relation to Fire Intensity: Consequences for Legume Germination and Fire Management in South-Eastern Australia. Journal of Applied Ecology. 1995, 32 (1): 76-84.

[14] D. Qiu, W. Zefei. The impact of silvicultural use of fire on soil temperature of the mixed coniferous and broad-leaved forests. 2018, 46 (04): 63-66.

[15] Parsons A. Field guide for mapping post-fire soil burn severity. General Technical Report RMRS-GTR-243. USDA Forest Service, Fort Collins [R]., 2010.

[16] Mataix-Solera J, Arcenegui V, Tessler N, et al. Soil properties as key factors controlling water repellency in fire-affected areas: Evidences from burned sites in Spain and Israel. CATENA. 2013, 108: 6-13.

[17] Zhang N, Renduo. Determination of Soil Sorptivity and Hydraulic Conductivity from the Disk Infiltrometer. Soil Science Society of America Journal. 1997, 61 (4): 1024-1030.

[18] Badía, D., López-García, S., Martí, C., et al. 2017. Burn effects on soil properties associated to heat transfer under contrasting moisture content. Science of the Total Environment, 601-602: 1119-1128.

[19] Bradstock R A, Auld T D, Ellis M E, et al. Soil temperatures during bushfires in semi-arid, mallee shrubland. Austral Ecology. 1992, 17 (4): 433-440.

[20] Beyers J L, Brown J K, Busse M D, et al. Wildland fire in ecosystems: effects of fire on soil and water. Fort Collins: Rocky Mountain Research Station, 2005.

[21] Loudermilk, E. L., O'Brien, J. J., Mitchell, R. J. et al. 2012. Linking complex forest fuel structure and fire behaviour at fine scales. International Journal of Wildland Fire, 21 (7): 882-893.

[22] Key, C. H. and Benson, N. C., 2006. Landscape Assessment (LA) Sampling and Analysis Methods. In: D. C. Lutes (eds.), FIREMON: Fire Effects Monitoring and Inventory System. United States Department of Agriculture. 